УДК 330

\title{
К ВОПРОСУ О СОЦИАЛЬНОМ ДОВЕРИИ В СОВРЕМЕННЫХ УСЛОВИЯХ
}

\author{
Фаркова Наталья Анатольевна \\ канд. физ.-мат.наук, доцент \\ Дипломатическая академия МИД России
}

\begin{abstract}
Аннотация: Доверие часто считается ключевым элементов для здорового функционирования институтов и демократии. Без преувеличения можно сказать, что доверие к институтам является основой системы и важным условием ее эффективности. Вопрос повышения доверия, анализ его роли и влияния на различные аспекты жизни, как индивида, так и государств, стал особенно актуален в связи с изменениями постпандемийного периода.
\end{abstract}

Ключевые слова: Доверие, недоверие, современное общество, социальный институт.

\section{TO THE QUESTION OF SOCIAL TRUST IN MODERN CONDITIONS}

\section{Farkova Natalia Anatolievna}

Abstrakt: Trust is often considered a key element for the healthy functioning of institutions and democracy. It is no exaggeration to say that trust in institutions is the foundation of the system and an important condition for its effectiveness. The issue of increasing trust, analyzing its role and influence on various aspects of life, both of an individual and of states, has become especially relevant in connection with the changes in the post-pandemic period.

Key words: Trust, distrust, modern society, social institution.

Сегодня, как никогда ранее, даже и в периоды серьезных социальных потрясений и переходов обществ к новой стадии развития, возрос интерес в теме доверия. Введенный в 2020 году мировой локдаун, дал возможность людям обратиться к осмыслению многих социальных, психологических, 


\section{НАУКА, ОБЩЕСТВО, КУЛЬТУРА: ПРОБЛЕМЫ И ПЕРСПЕКТИВЫ ВЗАИМОДЕЙСТВИЯ В СОВРЕМЕННОМ МИРЕ}

политических, культурных аспектов жизни. При стабильном общественном устройстве к теме доверия, проводя различные социологические опросы, обращаются в связи с надеждами на экономический рост и сохранение социальной стабильности. Что понимается под доверием, насколько представление о доверии или понимание его одинаково или близко - вопрос открытый. Поэтому и результаты подобных исследований неоднозначны.

Согласно словарю Ожегова доверие - «уверенность в чьей-либо добросовестности, искренности, в правильности чего-нибудь и основанное на этом отношение к кому-нибудь, чему-нибудь». Доверие лежит в основе не только межличностных отношений, но является базисом и для социальных институтов. Недоверие широких слоев населения или оппозиционных партий к политическому режиму может стать мощным ускорителем преобразований общества и государства.

Поэтому при кажущейся простоте понятия, доверие часто считается ключевым элементом для здорового функционирования институтов и демократии. Феномен доверия из российских ученых исследовали психологи Т.П. Скрипкина и В.П. Зинченко. Первый автор рассматривал доверие как разновидность веры. У Зинченко доверие - «аффективное предвосхищение». Отметим, что советская ментальность предполагала и настаивала на доверии к неверифицируемым абстракциям - идеалам и идеям. Не исключено, что недоверие, которое можно наблюдать в постсоветское время, является реакцией на идеологические ценности предшествующего периода. Тема недоверия - это отдельный вопрос и изучать его необходимо отдельно, здесь есть свои аспекты, связанные с ментальностью тех или иных народов, а также научных школ и философских направлений. Известная кембриджская школа Уайтхеда, Ч. Брода и Дж.Э.Мура считала, что признаком «цивилизованного» человека является «недоверие ко всяким абстракциям, реальность которых невозможно доказать» [3].

Считается, что доверие можно подорвать, а насколько возможно восстановить доверие? Почетный профессор Кембриджского университета и член Палаты лордов в Великобритании Онора О’Нил, говоря о стереотипном мнении, что в современном мире доверия стало меньше, на встрече со студентами Назарбаев Университета в 2017 году, отмечала, что доверия стало меньше в одной области, но, возможно, его стало больше в другой области. И, действительно, при переходе к цифровой экономике в России, например, частным 


\section{НАУКА, ОБЩЕСТВО, КУЛЬТУРА: ПРОБЛЕМЫ И ПЕРСПЕКТИВЫ ВЗАИМОДЕЙСТВИЯ В СОВРЕМЕННОМ МИРЕ}

цифровым сервисам доверяют больше, чем правительству - соответственно 59\% и 49\%. В 2020 году лишь 34\% россиян доверяло государству и бизнесу. По оценкам французских экономистов, уровень ВВП на душу населения в России был бы на 69\% выше, если бы уровень доверия в обществе был бы, как в Швеции. Для сравнения, если в Швеции 63\% граждан доверяют большинству людей, то в России только $25 \%$.

В попытках правительства РФ превратить страну в сервисное, ориентированное на клиента государство, предпринимаются меры, нацеленные на рост доверия. Но сопоставления с международными данными показывают, что доверие граждан к властям в значительной мере зависит не от качества услуг, а от доверия к полиции, а у России оно, увы, низкое. Поэтому усилия правительства при определенном реальном экономическом эффекте не приведут к ощутимому росту доверия, если не проводить реформу силовых органов власти. Один из вариантов повышения доверия в государство, предлагаемый экспертами, состоит в развитии партисипаторного бюджетирования и введения селективных налогов.

Относительно стереотипного мнения о доверии с точки зрения цели надо больше доверять - отметим, что стремиться доверять больше следует тем, кто заслуживает доверия, но не тем, кто его не заслуживает. Здесь вспоминаются в первую очередь организаторы различных финансовых пирамид: да, мы слишком много доверяем. Доверять больше - это неразумная цель в нашей жизни. Скорее цель - доверять или не доверять разумно. И, конечно, здесь речь должна идти в первую очередь о надёжности, а также честности и компетентности. В этом оценка того, насколько можно доверять в определенных отношениях. Отметим, что надёжность важнее доверия как такового. Доверие - это реакция. Надёжность - это то, что нам необходимо оценить. Создаются системы оценок для всех видов институтов, специалистов, служащих и т.д., которые помогают оценить их надёжность. Но многие из этих систем имеют и обратный эффект. Они не работают так, как планировалось. Например, введение балльно - рейтинговый системы оценивания успеваемости студентов или составление отчетов учителей, преподавателей, медиков, когда бумажная работа занимает больше времени, чем фактическая. Таким образом, ставя цель повышения доверия или его восстановления, надо прежде всего думать о надёжности. 


\section{НАУКА, ОБЩЕСТВО, КУЛЬТУРА: ПРОБЛЕМЫ И ПЕРСПЕКТИВЫ ВЗАИМОДЕЙСТВИЯ В СОВРЕМЕННОМ МИРЕ}

В период пандемии доверие было подорвано не только между людьми, но и между целыми странами, что отразилось на экономике и отношениях между государствами. Исследования ВШЭ [4] пришли к выводу, что ВВП стран зависит от доверия людей друг другу. А именно, анализ по 91 стране мира, показал, что при повышении уровня доверия на 10 процентных пунктов, при прочих равных - средний уровень ВВП на душу населения оказывается выше на $21 \%$.

Но доверие - лишь один из факторов успешного развития страны. Например, во Франции, на низкий уровень доверия друг к другу (он составляет 22\%), повлияли Вторая мировая война и оккупация, а Россия, пережив и Вторую мировую войну и сталинские репрессии, имеет $29 \%$ доверия друг к другу. При этом по уровню жизни Франция на 27 месте в мире, а Россия лишь на 52-ом. Видим, что уровень доверия в обществе не зависит от уровня жизни. Еще пример, в Индии доверяют друг другу более 90 процентов населения, а в Китае $-60 \%$.

Выше отмечалось, что честность одна из составляющих для повышения доверия. Пример Норвегии (страна, в которой не врут нигде, никому и никогда) указывает на то, что честность - это еще и залог благополучия. Норвегия, согласно индексам ООН, на высших позициях по образованности, уровню и продолжительности жизни населения с 2001 по 2019 годы. В российском обществе низкое доверие бизнесу, власти и медиа и из-за закрытости при принятии решений (например, снос исторических зданий, вырубка деревьев и т.Д) и безответственности. В возможность ведения честного бизнеса $62 \%$ россиян не верят. Внедрение принципов ESG, при котором бизнес принимает решения с учетом влияния на окружающую среду, общество и качество корпоративного управления и отражает в отчетах результаты социальной и экологической деятельности, помогло бы в определенной мере решить проблему недоверия в российском обществе. На Гайдаровском форуме А. Кудрин напомнил о рейтинге открытости министерств и ведомств, выпущенном в 2020 г. Счетной палатой и АНО «Информационная культура». Согласно результатам, треть министерств не отвечают на запросы граждан и две трети - на запросы журналистов. Игнорируя законы. К слову, в Индонезии, Китае, Саудовской Аравии бизнесу доверяют 70-80\% населения.

На национальную оборону и правоохранительные органы в 2020 году в России было выделено 5,6 трлн. руб. Для сравнения на социальную политику и 
здравоохранение - 6 трлн. руб. Таким образом, низкий уровень доверия в обществе ведет к увеличению расходов на надзорные органы. Экономисты доказали, что более высокий уровень доверия в обществе снижает транзакционные издержки, способствует экономическому росту, увеличивает продолжительность жизни. Можно сказать, что недоверие неэффективно.

С. Вершинин пишет [3]: «Недоверие традиционно сохраняется и в политической сфере. Это проявляется прежде всего в культуре управленческого недоверия, которая проявляется в централизации, усилении формы разнообразного контроля, авторитарном стиле управления, ориентации на сохранении порядка, а не на инновации и т.д. 1. Если недоверие распространяется централизованно, то смогут ли какие-либо региональные инициативы в политике, культуре, экономике, противостоять такому распространению?» И далее, отмечает, что в постсоветском обществе наблюдался в целом отрицательный баланс между доверием и недоверием: отсутствие доверия к экономической и политической системе заменяется доверием к отдельным личностям. И проблема как доверия, так и недоверия в итоге есть проблема выбора посредников в процессе социального взаимодействия. Поэтому стратегия выхода из ситуации социального недоверия - это поиски посредников, которыми могут быть отдельные харизматические личности, политические и культурные символы, национальные идеи, геополитические стратегии и т.д.

\section{Список литературы}

1. Скрипкина, Т.П. Психология доверия : учебное пособие для высших учебных заведений / Т.П. Скрипкина. - Москва : Академия - 2000. - 264 с.

2. Зинченко В.П. Психология доверия / В.П, Зинченко. - Самара: Издательство СИОКПП - 2001. - 104 с.

3. Вершинин С.Е. Соц. недоверие: парадигмы анализа, источники, функции (к постановке проблемы)/C.Е. Вершинин//Научный ежегодник Института философии и права Уральского отделения Рос. академии наук. 2007. №7. С. 61-74.

4. https://www.finam.ru/analysis/forecasts/doverie-i-nedoverie-v-rossii20181015-111223/

(C) Н.А. Фаркова, 2021 